\title{
ЗАГАЛЬНІ АСПЕКТИ ДОКАЗУВАННЯ У СПРАВАХ, ПОВ'ЯЗАНИХ ІЗ ПУБЛІЧНОЮ СЛУЖБОЮ
}

Марин П. П.

у статті визначено, що доказування у справах, пов'язаних з публічною службою, має такі загальні аспекти: 1) предметом доказів у справах, пов'язаних із публічною службою, $\epsilon$ відносини $з$ приводу прийняття, проходження та припинення публічної служби публічного службовця, який має спеціальний адміністративно-правовий статус і виконував владно-управлінські функції; 2) більшість справ, пов'язанuх із публічною службою, ґрунтуються на письмових доказах як основних засобах доказування, тому їх особливістю $\epsilon$ незначне використання засобів доказування, оскільки такі провадження здійснюється у порядку спрощеного позовного провадження і здебільшого не використовується показання сторін як засіб доказів; 3) у справах, пов'язаних із публічною службою, обов'язок доказування переважно покладається на відповідача - суб'єкта владних повноважень, який повинен довести суду, що владна діяльність з приводу прийняття, проходження та припинення публічної служби $\epsilon$ правомірною щодо конкретного публічного службовця, а публічний службовець як позивач повинен лише обгрунтувати свої позовні вимоги відповідно до норм законодавства.

Ключові слова: адміністративне судочинство, докази, звільнення, публічна служба, публічний службовець, публічно-правовий спір, справи, пов'язані з публічною службою, суб'єкт владних повноважень.

B cтатье определено, что доказывание по делам, связанным с публичной службой, имеет такие общие аспекты: 1) предметом доказательств по делам, связанным с публичной службой, являются отношения касательно принятия, прохождения и прекращения публичной службы публичного служащего, который имел специальный административно-правовой статус и выполнял властно-управленческие функции; 2) большинство дел, связанных с публичной службой, основываются на письменных доказательствах как основных средствах доказывания, поэтому их особенностью является незначительное использование средств доказывания, ведь такие производства осуществляется в порядке упрощенного искового производства, в большинстве случаев не используются показания сторон как средство доказательств; 3) по делам, связанным с публичной службой, обязанность доказывания в большей степени возлагается на ответчика - субъекта властных полномочий, который должен доказать суду, что властная деятельность касательно принятия, прохождения и прекращения публичной службы правомерна в отношении конкретного публичного служащего, а публичный служащий как истец должен лишь обосновать свои исковые требования в соответствии с нормами законодательства.

Ключевые слова: административное судопроизвод ство, доказательства, освобождение, публичная служба, публичный служащий, публично-правовой спор, дела, связанные с публичной службой, субъект властных полномочий.

The article determines that the evidence in public service cases has the following general aspects: 1) the subject matter of evidence in public service cases is the relationship regarding the acceptance, passage and termination of public service by a public official who has special administrative, legal status and performed power-management functions; 2) most public service cases are based on written evidence as the primary means of proof, so the peculiarity of such is the lack of use of means of proof, since such proceedings are carried out in the order of summary litigation, so in most cases the parties' evidence is not used as a means of proof. I, who has a special administrative and legal status and has performed managerial and administrative functions; 3) in cases involving public service, the burden of proof rests with the defendant, the subject of power, who must prove to the court that his or her public activity concerning the acceptance, passage and termination of public service is legitimate in relation to a particular public service the public servant, and the public servant, as the plaintiff, must only substantiate his claim in accordance with the rules of law.

It is outlined that there are four elements to procedural proof: the subject of proof; the subject of proof; means of proof and activities for the collection, investigation, verification, processing, evaluation and use of evidence. It has been found that cases involving the public service are characterized by little use of the means of evidence, since, in most cases, they are carried out in the order of summary litigation without using the evidence of the parties as a means of proof. Most such cases are based on the written evidence that underlies such cases.

It is emphasized that in cases related to the public service the burden of proof rests with the defendant - the subject of power, who must prove to the court that his own activity concerning the acceptance, passage and termination of public service is legitimate in relation to a specific a public servant, and a public servant, as a plaintiff, must only substantiate his claim in accordance with the rules of law.

Key words: administrative proceedings, evidence, dismissal, public service, public servant, public-law dispute, public service cases, subject of authority.

Постановка проблеми та її актуальність. Проблеми доказування в адміністративному судочинстві $\epsilon$ важливим питанням як у теорії, так і на практиці. Всебічне та повне дослідження доказів, на підставі яких буде винесено судове рішення, може здійснюватися лише при використанні всіх можливих засобів доказування у суді $[1$, с. 86$]$.

Засоби доказування в адміністративному судочинстві України відрізняються від засобів доказування в інших процесах і мають такі особливості: найбільша кількість видів засобів доказування; часте використання письмових доказів, у тому числі електронних документів; визнання однією зі сторін публічно-правового спору обставин у справі, які доводить інша сторона, не $є$ обов' язковим для суду, який має можливість надати суб'єктивну оцінку цим обставинам [1, с. 86].

Одним із видів адміністративних справ $€$ справи, пов'язані з публічною службою, загальні аспекти доказування яких $\epsilon$ актуальним викликом як для вченихадміністративістів, так і для публічних службовців.

Марин П. П., 2019 
Аналіз останніх досліджень і публікацій. Сфера публічної служби з позиції адміністративного судочинства $\epsilon$ досить актуальним предметом дослідження, якому приділяли увагу у свої наукових працях В. Бевзенко, В. Васильківська, Н. Гладка, М. Іншин, І. Качур, В. Косик, Л. Кошелева, Р. Куйбіда, В. Поплавський, К. Тимошенко, Н. Хлібороб, Ю. Цвіркун, М. Цуркан та інші, однак цілісних новітніх досліджень натепер у науковій літературі обмаль, тому ця проблематика потребує сучасних наукових викликів.

Мета статті полягає в тому, щоб на базі дослідження позицій вчених-юристів, нормативно-правової бази адміністративно-процесуального права визначити загальні аспекти доказування у справах, пов'язаних із публічною службою.

Виклад основного матеріалу. Спори з приводу прийняття громадян на публічну службу, їі проходження, звільнення з публічної служби належать до малозначних справ, тому відповідно до Кодексу адміністративного судочинства України (далі - КАСУ) [4] розглядаються у порядку спрощеного позовного провадження.

Відповідно до ст. 72 КАСУ доказами в адміністративному судочинстві $\epsilon$ будь-які дані, на підставі яких суд встановлює наявність або відсутність обставин (фактів), що обґрунтовують вимоги і заперечення учасників справи, та інші обставини, які мають значення для правильного вирішення справи [4].

Докази можуть реалізовуватися і через певний загальний процес - доказування. В. Косик вважає, що доказування у сфері проваджень в адміністративних справах - це врегульована правовими нормами діяльність адміністративного суду та учасників адміністративного процесу, спрямована на виявлення, збирання i закріплення, перевірку та оцінювання доказів для отримання достовірного знання. Останню слід розглядати у двох аспектах: як розумовий процес і як правову процедуру [6, с. 99-103].

Я. Калмикова вважає, що «доказування в адміністративному судочинстві» - це почуттєва розумова логічна діяльність із виявлення, витребування, збирання, закріплення, перевірки й оцінки доказів, їх процесуальних джерел адміністративним судом та учасниками адміністративної справи, спрямована на встановлення фактичних обставин публічно-правового спору, прав та обов'язків учасників спірних правовідносин, необхідних для правильного вирішення справи [3, с. 101]. Докази - це певні юридичні факти, які стають відомими для обставин справи за допомогою засобів доказування під час процесу доказування.

Предметом доказів у справах, пов'язаних із публічною службою, $\epsilon$ відносини з приводу прийняття, проходження та припинення публічної служби публічного службовця, який має спеціальний адміністративно-правовий статус і виконував владно-управлінські функції.

Засоби доказування - це чітко визначені процесуальним законом способи (пояснень сторін, третіх осіб та їхніх представників, показань свідків, письмових і речових доказів, висновків експертів), встановлення будь-яких фактичних даних, які для суду $\epsilon$ доказами [8, с. 30]. Згідно зі ст. 72 КАСУ докази як фактичні дані встановлюються такими засобами: 1) письмовими, речовими і електронними доказами; 2) висновками експертів; 3) показаннями свідків [4].

Задля того, щоб правильно та своєчасно розглянути і вирішити правовий спір по суті, захистити порушені чи оспорювані права, свободи та законні інтереси, суду необхідно встановити обставини справи, тобто отримати достовірні знання про ці обставини в результаті проведеного процесу; правильно кваліфікувати ці обставини, тобто визначити норми права, які мають застосовуватися; правильно застосовувати норми матеріального права до встановлених обставин [6, с. 99-103].

Процес доказування в адміністративному судочинстві складається з трьох етапів, які послідовно змінюються один одним: 1) збирання доказів як початкового етапу, протягом якого адміністративний суд та учасники адміністративного судочинства здійснюють сукупність процесуальних дій, спрямованих на виявлення доказів; 2) дослідження доказів як подальшого етапу, під час якого адміністративний суд та учасники адміністративного судочинства безпосередньо сприймають докази; 3) оцінки доказів як завершального етапу, під час якого має місце розумова діяльність суб'єктів доказування, спрямована на визначення належності, допустимості, достовірності кожного доказу окремо, а також достатності і взаємного зв'язку доказів у їх сукупності. На кожному з цих етапів має місце як процесуальна, так і розумова діяльність представників адміністративного суду та учасників адміністративного провадження, яка складає зміст доказування [5, с. 84].

Виокремлюючи такі критерії як джерело отримання відомостей про обставини публічно-правового спору; зв'язок доказів із обставинами, що підлягають доказуванню; спосіб утворення (процес формування); мета доказування; обставини, які обтяжують чи пом'якшують відповідальність; характер отриманої інформації; методи виявлення; строк подання доказів, можна повно, всебічно і об'єктивно з'ясувати обставини кожної справи [6, с. 99-103].

Процесуальному доказуванню притаманні чотири елементи: предмет доказування; суб'єкт доказування; засіб доказування та діяльність зі збирання, дослідження, перевірки, переробки, оцінки та використання доказів. Ці чотири елементи реалізуються у чотирьох видах діяльності: пізнавальна (інформаційно-евристична) діяльність; комунікативна (фіксація і забезпечення передачі фактичних даних у часі й просторі); засвідчувальна (підтвердження достовірності фактичних даних); обґрунтовуюча діяльність (використання доказів для встановлення істини). У процесі пізнавальної діяльності виявляються джерела доказової інформації. На комунікативну діяльність покладається завдання фіксації отриманої інформації, іiї процесуальне оформлення та пристосування до використання на стадії вирішення. Засвідчувальна діяльність спрямована на встановлення достовірності зібраних доказів [6, с. 99-103].

При розгляді справи за правилами спрощеного позовного провадження суд досліджує докази і письмові пояснення, викладені у заявах по суті справи, у випадку розгляду справи з повідомленням (викликом) учасників справи також заслуховує їхні усні пояснення [4]. Тобто, справи, пов'язані з публічною службою, характеризуються незначним використанням засобів доказів, адже здійснюються у порядку спрощеного позовного провадження в більшості випадків без використання показань сторін як засобу доказів. Більшість таких справ ґрунтується на письмових доказах, що $є$ основою таких справ.

Учасники справи подають докази у справі безпосередньо до суду. Позивач, особи, яким законом надано право звертатися до суду в інтересах інших осіб, повинні 
подати докази разом із поданням позовної заяви. Відповідач, третя особа, яка не заявляє самостійних вимог щодо предмета спору, повинні подати суду докази разом із поданням відзиву або письмових пояснень третьої особи. Якщо доказ не може бути поданий у встановлений законом строк із об'єктивних причин, учасник справи повинен про це письмово повідомити суд і зазначити доказ, який не може бути подано; причини, з яких доказ не може бути подано у зазначений строк. Учасник справи також повинен надати докази, які підтверджують, що він здійснив усі залежні від нього дії, спрямовані на отримання відповідного доказу [4].

Кожна сторона повинна довести ті обставини, на яких ґрунтуються ї̈ вимоги та заперечення [4], при цьому у справах з приводу прийняття на публічну службу, іiі проходження та звільнення з неї обов'язок щодо доказування правомірності своїх рішень, дій чи бездіяльності покладається на суб'єкта владних повноважень - відповідача [7; 2]. Цю правову позицію майже дослівно взято з постанови Верховного Суду України від 13 березня 2007 року у справі за позовом $\epsilon$. Жовтяка до Президента України про скасування Указу Президента України від 24 травня 2006 року № 434/2006 «Про звільнення $Є$. Жовтяка 3 посади голови Київської обласної державної адміністрації» та поновлення на посаді: «ч. 2 ст. 71 КАС України визначено, що в адміністративних справах про протиправність рішень, дій чи бездіяльності суб'єкта владних повноважень обов'язок щодо доказування правомірності свого рішення, дії чи бездіяльності покладається на відповідача, якщо він заперечує проти адміністративного позову. Обов'язок щодо доказування правомірності свого рішення покладається на відповідача і у справах про поновлення на публічній службі» [7; 2].

Значення цієї позиції полягає у тому, що обов'язок суб'єкта владних повноважень доказувати правомірність своїх рішень, дій чи бездіяльності поширений не лише на спори фізичних та юридичних осіб із суб'єктом владних повноважень щодо оскарження його рішень, дій чи бездіяльності, а й на інші адміністративні справи про протиправність його рішень, дій чи бездіяльності, зокрема спори з відносин публічної служби [7; 2]. Тобто, у справах, пов'язаних із публічною службою, обов'язок доказування здебільшого покладається на відповідача суб'єкта владних повноважень, який повинен довести суду, що владна діяльність із приводу прийняття, проходження та припинення публічної служби $є$ правомірною щодо конкретного публічного службовця, а публічний службовець як позивач повинен лише обґрунтувати свої позовні вимоги відповідно до норм законодавства.

Як і в будь-якому адміністративному провадженні, у справах, пов'язаних із публічною службою, суд оцінює докази, які $є$ у справі, за своїм внутрішнім переконанням, що ґрунтується на їх безпосередньому, всебічному, повному та об'єктивному дослідженні. Жодні докази не мають для суду наперед встановленої сили. Суд оцінює належність, допустимість, досто- вірність кожного доказу окремо, а також достатність і взаємний зв'язок доказів у їх сукупності. Суд надає оцінку як зібраним у справі доказам загалом, так і кожному доказу (групі однотипних доказів), які міститься у справі, мотивує відхилення або врахування кожного доказу (групи доказів) [4].

Висновки. Доказування у справах, пов'язаних із публічною службою, має такі загальні аспекти: 1) предметом доказів у справах, пов' язаних із публічною службою, $є$ відносини з приводу прийняття, проходження та припинення публічної служби публічного службовця, який має спеціальний адміністративно-правовий статус і виконував владно-управлінські функції; 2) більшість справ, пов'язаних із публічною службою, ґрунтуються на письмових доказах як основних засобах доказування, тому їх особливістю $€$ незначне використання засобів доказування, адже такі провадження здійснюється у порядку спрощеного позовного провадження, тому в більшості випадків не використовується показання сторін як засіб доказів; 3) у справах, пов'язаних із публічною службою, обов'язок доказування здебільшого покладається на відповідача - суб'єкта владних повноважень, який повинен довести суду, що владна діяльність із приводу прийняття, проходження та припинення публічної служби є правомірною щодо конкретного публічного службовця, а публічний службовець як позивач повинен лише обґрунтувати свої позовні вимоги відповідно до норм законодавства.

\section{Література}

1. Галай В.О. Характеристика засобів доказування в адміністративному судочинстві. Наше право. 2013. № 6. С. 82-86.

2. Єдиний державний реєстр судових рішень : офіційний веб-сайт. 2018. URL: http: //www.reyestr.court.gov.ua/.

3. Калмикова Я.С. Визначення доказів і доказування в адміністративному судочинстві. Проблеми законності. 2011. Вип. 116. С. 94-101.

4. Кодекс адміністративного судочинства України від 06.07.2005. Відомості Верховної Ради України. 2005. № 35-36, 37. Ст. 446.

5. Король В.В. Зміст процесу доказування в адміністративному судочинстві України. Європейські перспективи. 2013. № 13. С. 79-84.

6. Косик В.В. Деякі аспекти поняття доказування у сфері проваджень в адміністративних справах. Вісник Харківського національного університету внутрішніх справ. 2012. № 4(2). С. 99-103.

7. Куйбіда Р. Окремі позиції Верховного Суду України у спорах із відносин публічної служби. Центр політико-правових реформ : офіційний веб-сайт. 2018. URL: https: / /www.pravo.org.ua/ua/news/2622.

8. Мельник М. Засоби, джерела доказування в адміністративному судочинстві України: поняття та особливості. Вiче. 2010. № 16. С. 29-32.

Марин П. П., здобувач наукового ступеня кандидата юридичних наук Науково-дослідного інституту публічного права 